\title{
What is Astragalus wiesneri? Disentangling a new species from its relatives in section Anthylloidei
}

\author{
Amir H. PAHLEVANI ${ }^{*}$, Ali Asghar MAASSOUMI ${ }^{2}$, Shahrokh KAZEMPOUR-OSALOO ${ }^{3}$ \\ ${ }^{1}$ Department of Botany, Iranian Research Institute of Plant Protection, Agricultural Research, Education and Extension Organization (AREEO), \\ Tehran 1454-19395, Iran. \\ ${ }^{2}$ Research institute of Forests and Rangelands, P. O. box 13185-116, Tehran, Iran. \\ ${ }^{3}$ Department of Plant Biology, Faculty of Biological Sciences, Tarbiat Modares University, Tehran 14115-154, Iran. \\ *Correspondence: amirpahlevani1977@gmail.com \\ ${ }^{1}$ https://orcid.org/0000-0001-6827-7100, ${ }^{2}$ https://orcid.org/0000-0002-0134-4986 \\ ${ }^{3}$ https://orcid.org/000-0002-6275-1673
}

\begin{abstract}
Here, we describe and illustrate a new alpine species of Astragalus sect. Anthylloidei from Iran. Astragalus wiesneri sp. nov., an interesting and rare species, is only known from the type locality in the Bul Mountain (near Eghlid city) in the southern Zagros Mountains. The new species is compared with close relatives, including A. nigrohirsutus and A. lalesarensis, which are also endemic to Iran. In addition, we assembled a dataset of nrDNA ITS sequences of 21 species (22 accessions) representing $A$. sect. Anthylloidei and ten species of other related spiny-cushion forming sections. Maximum likelihood methods and Bayesian Inference retrieved $A$. wiesneri sister to $A$. nigrohirsutus, a species growing in the same area as the new species. The description of $A$. wiesneri is presented along with a distribution map, some ecological information, field images, conservation status, and pertinent notes.
\end{abstract}

Keywords. Biodiversity, Fabaceae, flora of Iran, Irano-Turanian Region, southwest Asia, taxonomy, Zagros Mountains.
Resumen. Se describe e ilustra una nueva especie alpina de Irán, perteneciente a Astragalus sect. Anthylloidei. Astragalus wiesneri sp. nov., una especie hasta ahora desconocida, crece en las zonas altas del Monte Bul al sur de los Montes Zagros. La nueva especie se comparó con especies afines incluyendo $A$. nigrohirsutus y A. lalesarensis, también endémicas de Irán. Además del examen morfológico, se construyó una matriz de datos moleculares representando 21 especies (22 especímenes) de $A$. sect. Anthylloidei y 10 especies de otras secciones del género que incluyen arbustos almohadillados espinosos. Se realizaron análisis filogenéticos de secuencias de la región ITS del ADN ribosómico nuclear. Los análisis moleculares indican que $A$. wiesneri es hermana de $A$. nigrohirsutus, una especie con la que vive en simpatría. La descripción morfológica de $A$. wiesneri va acompañada de un mapa de distribución, información ecológica, imágenes de campo, estado de conservación y comentarios relevantes.

Palabras clave. Biodiversity, Fabaceae, flora de Irán, Montes Zagros, Región Irano-Turaniana, taxonomía, suroeste asiático.

How to cite this article: Pahlevani A.H., Maassoumi A.A. \& Kazempour-Osaloo S. 2020. What is Astragalus wiesneri? Disentangling a new species from its relatives in section Anthylloidei. Anales del Jardín Botánico de Madrid 77: e103. https://doi.org/10.3989/ajbm.2573

Title in Spanish: ¿Qué es Astragalus wiesneri? Delimitando una nueva especie en la sección Anthylloidei.

Associate Editor: Ricarda Riina. Received: 6 September 2020; accepted: 2 December 2020; published online: 4 January 2021.

\section{INTRODUCTION}

Astragalus L. with about 3150 species is the largest genus of flowering plants (Maassoumi 2020a) distributed in northern temperate areas of the world. Most of its diversification history took place in the Old World (Podlech \& Zarre 2013; Maassoumi 2020a). Old World Astragalus is divided into 150 sections and roughly 2748 taxa (2560 species and 188 subspecies), of which c. 135 sections occur in SW Asia (Maassoumi 2020a). Twenty two sections are endemic and restricted to small geographical regions, and many other sections (111) show wider distribution areas. In SW Asia, Astragalus has over 1484 species (1024 endemics) distributed in all phytogeographical units and various habitats. The Irano-Turanian region with a relatively high number of endemics is one of the most important centers of speciation and endemism for the genus (Maassoumi 2020b). The number of species in the sections varies from one (e.g., sect. Plagiophaca Maassoumi \& Podlech) to more than 295 species in sect. Caprini DC. (Podlech 1988; Podlech \& Zarre 2013; Maassoumi 2020a). Astragalus sect. Anthylloidei DC. with 40 species is a rather large and morphologically complicated group, of which 29 species are endemic and restricted to some parts of SW Asian countries (Iran, Afghanistan and Turkey) and the 11 remaining ones are distributed in adjacent areas including south part of Central Asia (Turkmenistan and Uzbekistan, 5 species), Caucasus (Armenia, Azerbaijan and Dagestan, 3 species), Eeastern Mediterranean region 
(Syria and Lebanon, 2 species), and only one species occurs in Pakistan (Podlech \& Zarre 2013; Maassoumi 2020a). Iran with 30 species and 21 endemics of Astragalus sect. Anthylloidei is the most species-rich country both in terms of species number and endemics (Podlech \& Zarre 2013). Species in this section occur mostly in rocky limestone mountainous regions with a few species reaching the subnival-nival zones (Bornmüller 1937). Members of this group are recognized by their spiny-cushion habit, paripinnate (rarely imparipinnate) leaves, white basifixed hairs on stems and leaves but mixed with black hairs on inflorescences, and an inflated calyx surrounding an unilocular pods.

Recent molecular phylogenetic studies on the section, using nuclear and plastid DNA, indicated that some subspecies formerly described should be elevated to specific rank (Naderi-Safar \& al. 2014a, b). Lack of data on some Iranian endemic species and populations of Astragalus sect. Anthylloidei lead us to evaluate the phylogenetic relationships and the morphology of some poorly studied taxa.

While identifying plants collected from the Bul Mt., one of the most interesting Zagros Mountain ranges in the Fars province, a curious, mountain-dwelling species of $A$. sect. Anthylloidei attracted our attention. After close examination, comparison with the other members of the section, and performing a molecular phylogenetic analysis, we concluded that the species was new to science.

\section{History}

After Polak and Pichler's 1882 collections from Iran, Otto Stapf made an excursion to the Fars province and adjacent areas in southern Iran with the supporting from Memoires of Imperial Academy of Vienna (1885-86) (Stapf 1886). He managed to reach the alpine area of Abadeh, Eghlid, and Bul Mountain. Within his vast collection, he recognized an interesting, unknown Astragalus species, but he never published it. The specimen was later determined as a morphological variation of $A$. lalesarensis Bornm. by Joseph Bornmüller, a professional German botanist. Astragalus lalesarensis is another Iranian endemic species occurring in some alpine regions of the Kerman province (Bornmüller 1937). Stapf attached a small label on the K and WU duplicates where he indicated his intention to describe the new species after his Botany professor "Julius Wiesner" at the University of Vienna, but he never did. Later on, this name "A. wiesneri Stapf ex Bornm." was mistakenly included in Index Kewensis (Hill \& Salisbury 1947) as a valid name, however Bornmüller (1937) just determined the specimen (K 000911588) as A. lalesarensis and that some minor differences between these species could be related to the high alpine habitat at Bul Mt. The altitude reported by Bornmüller for the Stapf's collection was wrong $(14400 \mathrm{ft}=4800 \mathrm{~m})$ (Bornmüller 1937) because according to the collection label (K 000911588) it was collected at $11500 \mathrm{ft}(3500 \mathrm{~m})$, and the summit of Bul Mt. reaches roughly $4000 \mathrm{~m}$ elevation.

Following the mistake of Index Kewensis (Hill \& Salisbury 1947), in the revision of Astragalus sect. Megalocystis Bunge, a joint collaboration in Širjaevae fragmenta Astragalogica (Rechinger \& al. 1958), A. wiesneri was considered as a synonym of A. lalesarensis. Moreover, Lock and Simpson in their Legumes checklist (Lock \& Simpson 1991) continued listing this invalid name (A. wiesneri Bornm.). Later on the section was revised by Tietz \& Zarre (1994) and A. wiesneri was considered as a "nom. nud." There is no indication of the name $A$. wiesneri neither in the checklist of Astragalus of the Old World, nor Flora Iranica, nor Flora of Iran (Maassoumi 1998; Podlech \& al. 2001; Maassoumi 2016), however, in the Taxonomic revision of the genus Astragalus in the Old World this name is indicated for a specimen of A. lalesarensis (Podlech \& Zarre 2013).

\section{MATERIAL AND METHODS}

Specimens of some Astragalus sect. Anthylloidei from several herbaria such as IRAN, K, M, MSB, TARI, W, and WU as well as newly collected specimens from alpine region of Bul Mt. (Iran, Fars, Eghlid) by the first author during an excursion in spring 2019, were studied and identified using the relevant taxonomic literature and floras (Tietz \& Zarre 1994; Podlech \& al. 2001; Podlech \& Zarre 2013; Maassoumi 2016).

\section{Molecular study}

Total genomic DNA was isolated from fresh or dried leaf material using the modified CTAB method of Doyle \& Doyle (1987). The ITS nrDNA region was amplified using the primers ITS5m (Sang \& al. 1995) and ITS4 (White \& al. 1990). Polymerase chain reaction (PCR) was carried out in $20 \mu \mathrm{L}$ of final volume of mixture containing $1.0 \mu \mathrm{L}$ of template DNA $(5 \mathrm{ng} / \mu \mathrm{L}), 0.5 \mu \mathrm{L}$ of each primer $(10 \mathrm{pmol} / \mu \mathrm{L}), 10 \mu \mathrm{L}$ of the $2 \mathrm{X}$ Taq DNA polymerase Master Mix Red (Amplicon, Cat. No. 180301, Germany), and $8.0 \mu \mathrm{L}$ of sterile water. PCR consisted of 30 cycles of $50 \mathrm{~s}$ at $94{ }^{\circ} \mathrm{C}$ for template denaturation, $40 \mathrm{~s}$ at $53{ }^{\circ} \mathrm{C}$ for primer annealing, and $55 \mathrm{~s}$ at $72{ }^{\circ} \mathrm{C}$ for primer extension, followed by $7 \mathrm{~min}$ at $72{ }^{\circ} \mathrm{C}$ for completion of primer extension. PCR products were separated by electrophoresis in $1 \%$ agarose gel stained with ethidium bromide and were photographed with a UVI gel documentation system (UVItec, UK). The ITS nrDNA region was then sequenced using the BigDye Terminator Cycle Sequencing Ready Reaction Kit (Applied Biosystems, USA) with the same ITS5m and ITS4 primers in an ABI Prism 3730xl DNA Analyzer (Applied Biosystems, USA). 
For the phylogenetic reconstruction, 32 species belonging to A. sect. Anthylloidei and some other spiny-cushion forming sections were analyzed using the ITS nrDNA sequence data. Two non-spiny Astragalus (A. aegobromus Boiss. \& Hohen. and A. sinicus L.) were chosen as outgroups according to Naderi-Safar \& al. (2014a). Voucher information of the taxa used in the phylogenetic analysis and GenBank accession numbers are given in Appendix 1. The sequences for these species were aligned using MUSCLE (Edgar 2004), followed by manual adjustments. Variable and parsimoniously informative characters were calculated by MEGA X (Kumar \& al. 2018). Bayesian inference (BI) and maximum likelihood (ML) analysis were performed to reconstruct phylogenetic trees. For BI, model selection was based on the Akaike information criterion (AIC) estimated by jModelTest (Posada 2008). The analyses were performed using MrBayes 3.2.6 (Ronquist $\&$ al. 2012) as implemented in the CIPRES Science Gateway V. 3.3. (https://www.phylo.org; Miller \& al. 2010), with 10,000,000 Markov chain Monte Carlo (MCMC) generations and four Markov chains (i.e., one cold and three heated). MCMC started from a random tree and sampling one of every 100 generations with the first $25 \%$ of the trees discarded as burn-in. The remaining trees were used to generate a majority-rule consensus tree. Consensus clades with posterior probability (PP) are considered as a measure of clade support. ML trees were conducted using the online phylogenetic software W-IQ-TREE (Trifinopoulos \& al. 2016) available at http://iqtree.cibiv. univie.ac.at. The evolutionary model of ML analysis was selected under Model Finder software (Kalyaanamoorthy $\&$ al. 2017) implemented in IQ-TREE web server and then datasets in FASTA format imported. The bootstrap support was selected based on 5000 replicates with one search replicate per bootstrap replicate, and the other options were remained in the default setting. The selected evolutionary model for both methods is $\mathrm{K} 80+\mathrm{G}$. The Figtree version 1.4.4 (Rambaut 2018) available at https://github.com/ rambaut/figtree/releases was used to visualize the best tree with support values as well.

\section{Distribution map and assessment of conservation status}

The distribution map was prepared using existing herbarium specimens (B, IRAN, K, M, MSB, TARI, W, WU; Thiers 2020). Specimens were georeferenced using Microsoft Encarta 2008 or Google Earth. All georeferenced records were used to build a map for three species, including the new one, using DMAP software (Morton 2009), with the symbols representing the actual geographical coordinates.

Three endemic and rare species, A. lalesarensis, $A$. nigrohirsutus (Tietz \& Zarre) Borjian, Maassoumi \& Assadi and A. wiesneri sp. nov., were evaluated according to IUCN Red list categories (IUCN 2019). The threat status was evaluated using GeoCat, a browser-based tool (http://geocat.kew.org/, Bachman \& al. 2011). The extent of occurrence (EOO) and area of occupancy (AOO) in criterion B (IUCN 2019) were used to categorize the species threat status (IUCN 2019). To estimate the AOO, the sliding scale of $1 / 10$ th of the maximum distance between any pair of points, calculated by distance tool in Microsoft Encarta 2008, was applied in GeoCat.

\section{RESULTS AND DISCUSSION}

\section{Molecular phylogenetics}

The ITS nrDNA data matrix of 33 accessions, representing 32 species, included 614 nucleotide sites, of which 95 (15.5\%) were variable and 40 (6.5\%) were parsimoniously informative. Phylogenetic analysis of ITS nrDNA data recovered a paraphyletic section Anthylloidei, which is in agreement with the findings of a previous phylogenetic study (Naderi-Safar \& al. 2014a). The new species, $A$. wiesneri, is nested in a clade of 14 species, all members of sect. Anthylloidei (Fig. 4), and is most closely related to $A$. nigrohirsutus, another endemic species occurring in the southern part of Zagros Mts., including Bul Mt. where A. wiesneri was also collected (Fig. 5).

The new species might be confused with $A$. lalesarensis (Bornmüller 1937) but our phylogenetic results do not support a close relationship of $A$. wiesneri with that species (Fig. 4). Morphologically, the new species is recognizable by its small and dense caespitose habit (not loose/sparse), thin, flexible rachis, 2-2.5 (3) cm long (not rigid, thick, (3) 4-6 cm long), densely covered with ascending to patent hairs (not short appressed hairs), calyx densely covered with spreading hairs in fruit (not sparsely to glabrous). The most important morphological characters distinguishing A. lalesarensis, A. murinus Boiss., A. nigrohirsutus, and A. wiesneri are given in Table 2. A distribution map of all three species is shown in Figure 5.

\section{Taxonomic treatment}

Astragalus wiesneri Maassoumi \& Pahlevani, sp. nov. "Astragalus wiesneri" Stapf, in Sched. On a herbarium label [K 000911588]. Type: Iran, Fars, Eghlid, S Eghlid, Layshakaft, Bul Mt., 3046'39'N, 5244'26'E, 3600-3850 m, 20 Jun. 2019, Pahlevani \& Ghamghami 76643 (holotype IRAN; isotype TARI). Figs. 1, 2.

It differs from $A$. nigrohirsutus by its dense caespitose habit (not loose/sparse), thin rachis, 2-2.5 (3) $\mathrm{cm}$ long (not 5-20 cm, rigid), peduncle $1.5 \mathrm{~cm}$ long (not up to $20 \mathrm{~cm}$ long), inflorescence with 2-3 flowers (not with many remote flowers), inflated calyx $15 \mathrm{~mm}$ long (not 14-23 mm long), only covered with white hairs 

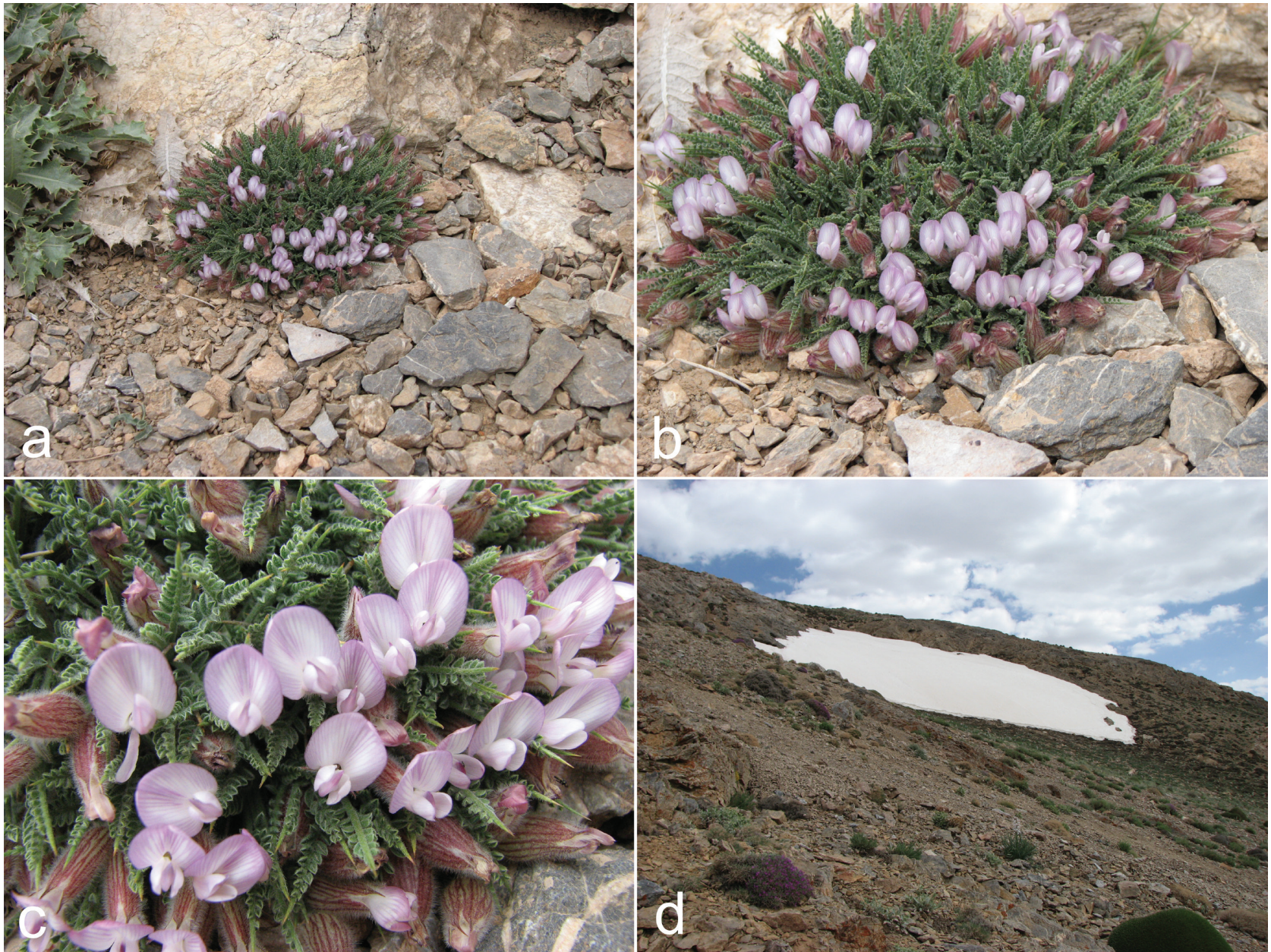

Fig. 1. Astragalus wiesneri, sp. nov.: a-c, plant in flower; d, habitat. Photo: A.H. Pahlevani.

(not mixed white and black hairs), ovary covered only with white hairs (not mixed white and black hairs).

Plant suffruticose to densely caespitose, woody at base, $10 \mathrm{~cm}$ tall and $15 \mathrm{~cm}$ in diameter. All vegetative parts densely covered with spreading to sub-appressed short hairs $0.5-1 \mathrm{~mm}$, on the calyx $2.5-3 \mathrm{~mm}$ long. Stipules $5 \mathrm{~mm}$ long, membranous, shortly lanceolate, $3 \mathrm{~mm}$ adnate to petiole, other side free from each other, free portion lanceolate, $2 \mathrm{~mm}$ long, densely covered with appressed hairs, ciliate on the margin. Leaves 2-2.5 (3) cm long, rachis thin, flexible, terminating to a distinct spine, $5 \mathrm{~mm}$ long; petioles short, thin, $1 \mathrm{~mm}$ long; leaflets 6-7 pairs, remote, oblong to obovate, small, $3 \mathrm{~mm}$ long and $2 \mathrm{~mm}$ wide, obtuse or rarely emarginate at apex, attenuate to the base, densely covered with spreading to ascending hairs; both petioles and rachis densely to loosely covered with appressed hairs, $0.5-1 \mathrm{~mm}$ long, upper side densely to sparsely hairy, lower side more densely hairy. Inflorescence pedunculate, peduncle $1.5 \mathrm{~cm}$ long, shorter than leaves, covered by more spreading hairs, raceme remote, with 2 flowers. Pedicel $2 \mathrm{~mm}$ long covered with spreading hairs. Bracts hairy, membranous, $4 \mathrm{~mm}$ long; bracteoles linear to lanceolate, hairy, $2.5 \mathrm{~mm}$ long, at the base of calyx tube. Calyx tubular, $15 \mathrm{~mm}$ long, covered with long appressed white hairs and purplish parallel venation in flowering time, slightly inflated in fruiting time; teeth subulate, $5 \mathrm{~mm}$ long. Corolla pale purplish to purple with darker purple venation. Standard $20 \mathrm{~mm}$ long; limb obovate, retuse to emarginate at apex, gradually attenuate toward the claw, inner side sparsely hairy; claw $10 \mathrm{~mm}$ long; wings $18 \mathrm{~mm}$ long, at the base with short auricle; claw $12 \mathrm{~mm}$ long; keel $17 \mathrm{~mm}$ long, limb obovate, triangular, $5 \mathrm{~mm}$ wide, claw $12 \mathrm{~mm}$ long. Ovary pilose, minutely stipitate, stipe $1 \mathrm{~mm}$ long. Pods unknown.

Distribution and habitat.-Iran (Fars province, Zagros Mts.). So far, A. wiesneri is only known from the Bul Mt. in the southern part of Zagros Mts. We made the second collection of this species after 135 years (it has been only collected before in 1885 by O. Stapf in the same locality). It grows in the alpine region (3500-3850 m) of the mountain 


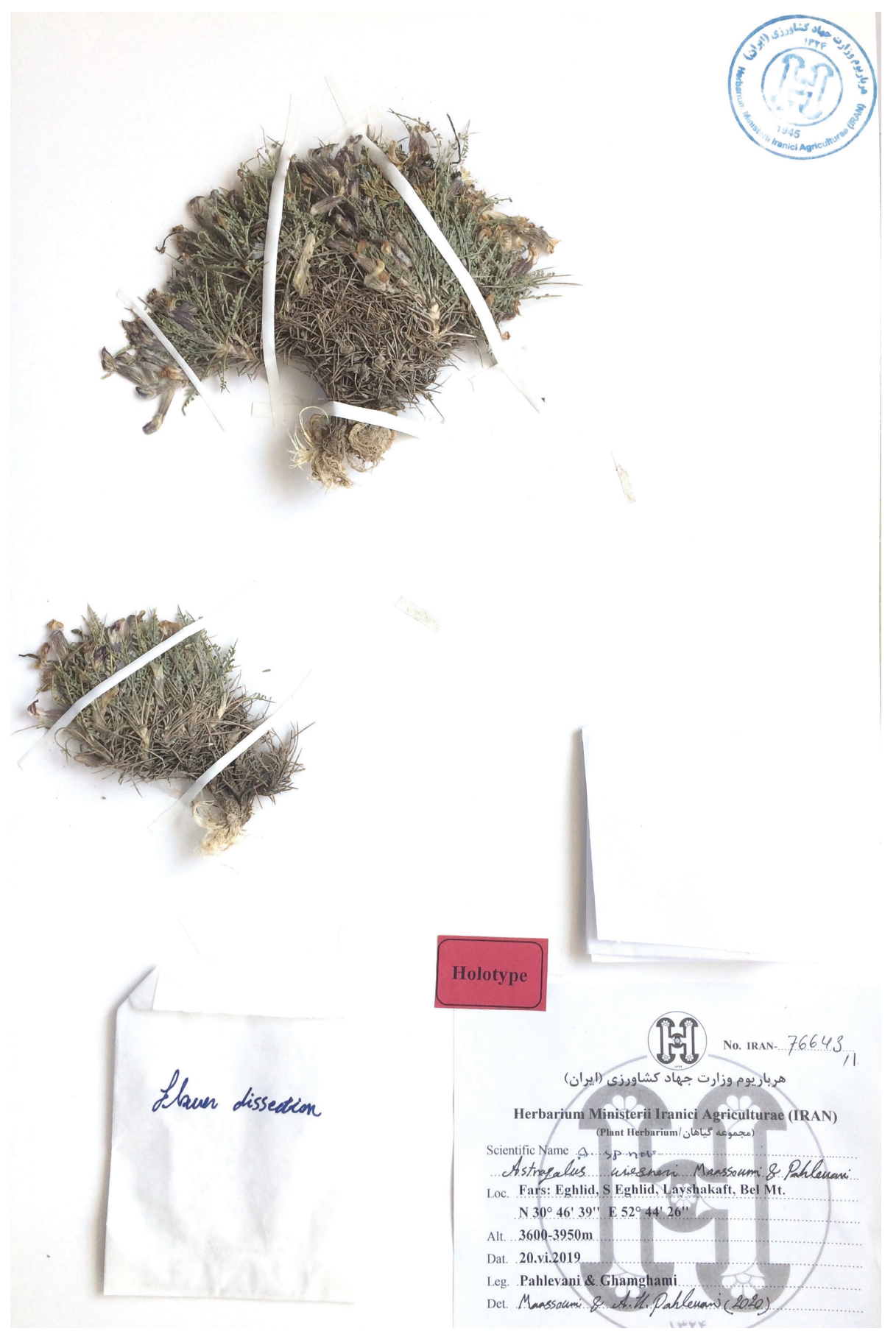

Fig. 2. Image of the holotype of Astragalus wiesneri (76643 IRAN).

on rocky limestone and screes near snow patches close to big boulders that shelter this plant against erosion and the high speed wind during the growth season (Fig. 1). Due to the harsh climatic and edaphic conditions in the region, a few chasmophytic species (Dielsiocharis kotschyi (Boiss.) O.E.Schulz and Corydalis rupestris Kotschy) along with several endemic to subendemic and rare species thrive in the same habitat: Asperula glomerata subsp. condensata (Ehrend.) Ehrend., Astragalus tenuiscapus Freyn \& Bornm., Cousinia cf. multiloba DC., Euphorbia aucheri Boiss., Micrantha multicaulis (Boiss.) Dvorak, Onosma stenosiphon Boiss., Pseudotrachydium depressum (Boiss.) Pimenov \& Kljuykov subsp. depressum and Zerdana anchonioides Boiss. 

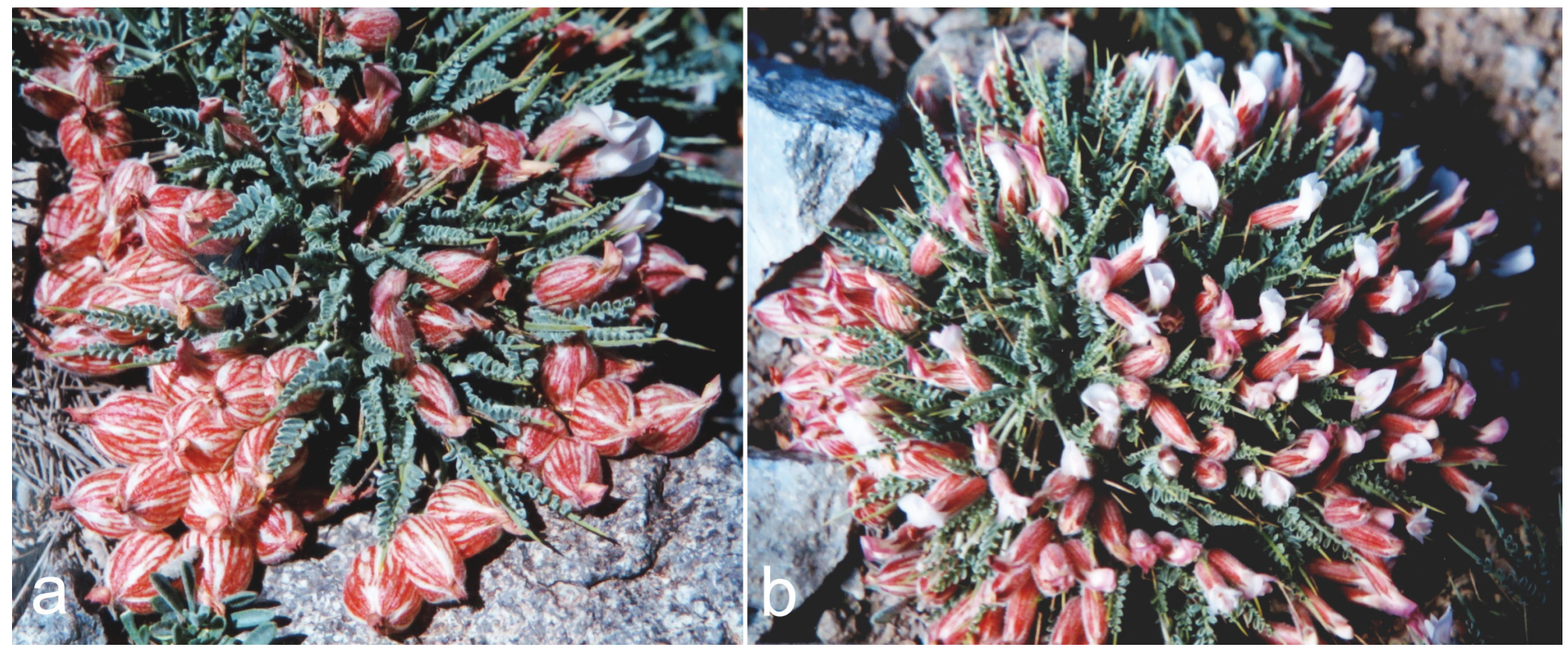

Fig. 3. Astragalus lalesarensis in the field: a-b, plant in flower. Photo: M. Mirtadzadini.

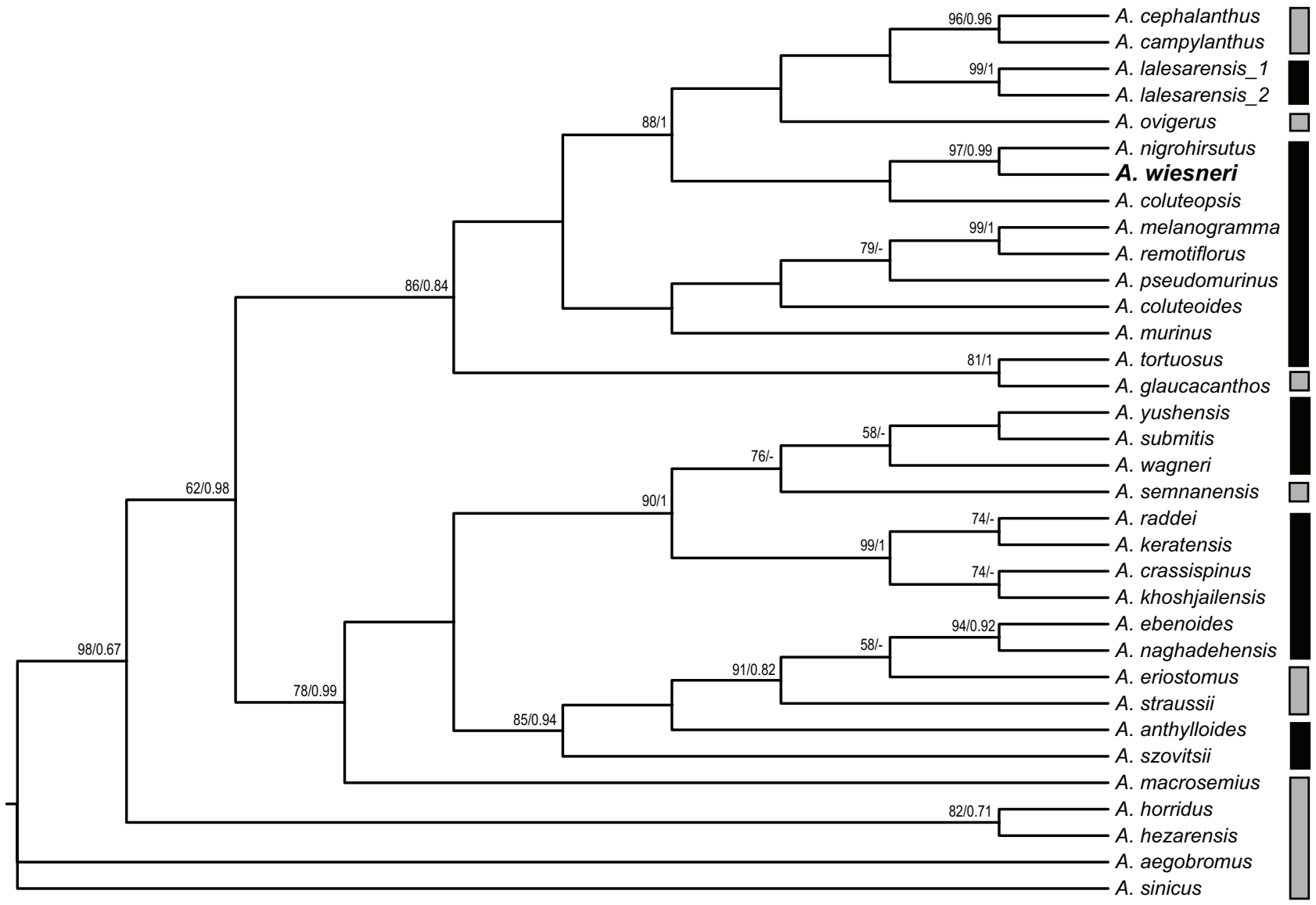

Fig. 4. Phylogenetic tree resulting from Maximum likelihood analysis of ITS nrDNA sequences of a selection of Astragalus species. The new species, $A$. wiesneri, is highlighted in bold. Species belonging to $A$. section Anthylloidei are indicated with black bars on the right; the rest of the species (gray bars) belong to 10 different sections of Astragalus. Bootstrap supports and posterior probabilities are indicated above branches, respectively. Values $<50 \%$ are not shown. 


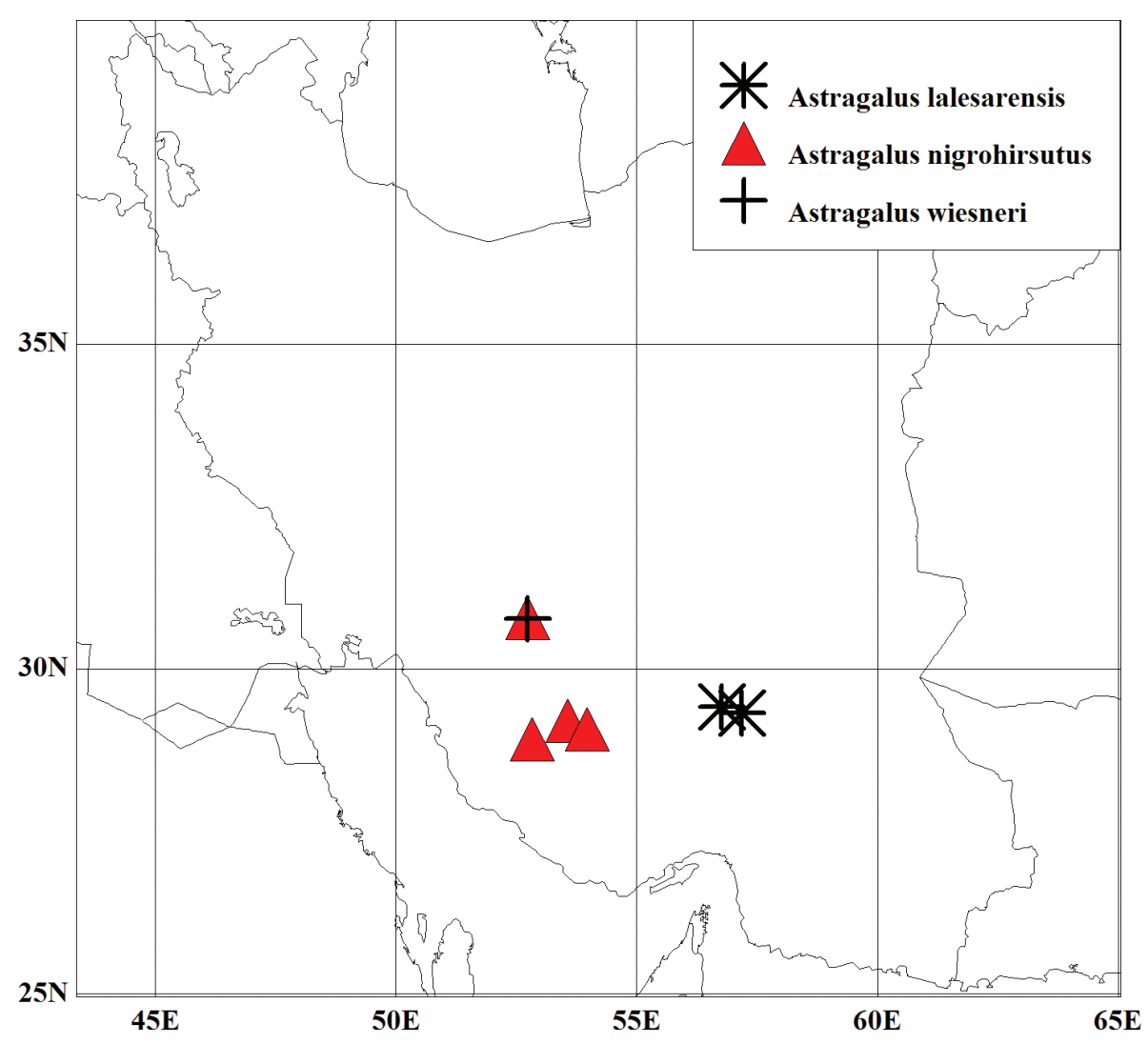

Fig. 5. Distribution map of the new species, Astragalus wiesneri, and two other species in Astragalus section Anthylloidei endemic to Iran.

Table 1. Checklist of the three Iranian endemic Astragalus species of section Anthylloidei. Hem.: hemicryptophyte; EOO: extent of occurrence; AOO: area of occupancy; CR: critically endangered; VU: vulnerable.

\begin{tabular}{llccccl}
\hline Species & Life form & Records & $\mathbf{E O O ~}\left(\mathbf{k m}^{\mathbf{2}}\right)$ & $\mathbf{A O O}\left(\mathbf{k m}^{\mathbf{2}}\right)$ & $\mathbf{1 0 \%}$ max. dist. $(\mathbf{k m})$ & Redlist category \\
\hline A. lalesarensis & Hem. & 2 & - & 32 & 4 & CR B2ab(i,ii,iv) [VU D2] \\
A. nigrohirsutus & Hem. & 4 & 11,540 & 1,936 & 22 & VU B1ab(i,ii,iv) \\
A. wiesneri & Hem. & 1 & $<100$ & $<10$ & - & CR B1+B2ab(iii) \\
\hline
\end{tabular}

Table 2. Main morphological characters distinguishing Astragalus lalesarensis, A. murinus, A. nigrohirsutus, and A. wiesneri sp. nov.

\begin{tabular}{|c|c|c|c|c|c|c|}
\hline Species & Habit & Calyx hairs & Peduncle & Rachis & Pod indument & Flowers \\
\hline A. lalesarensis & Lax caespitose & White & Shorter than leaves & rigid, thick (3) 4-6 cm & Sparsely hairy to glabrous & $2-3$ \\
\hline A. murinus & Dense to lax caespitose & Black and white & Shorter than leaves & rigid, thick $5-8 \mathrm{~cm}$ & Densely hairy, white & $2-6$ \\
\hline A. nigrohirsutus & Lax caespitose & Black and white & Longer than leaves & rigid, thick $5-20 \mathrm{~cm}$ & Hairy, black and white & Many \\
\hline A. wiesneri & Dense caespitose & White & Shorter than leaves & flexible, thin $2-2.5(3) \mathrm{cm}$ & Hairy, white & $2-3$ \\
\hline
\end{tabular}

Phenology. - Collected in flower in June.

Ethymology. - The epithet honors Dr. Julius R. von Wiesner (1838-1916), professor of Botany at the University of Vienna.

Conservation status. - The Red List categories of the three Irano-Turanian endemic species of Astragalus sect. Anthylloidei, A. lalesarensis, A. nigrohirsutus and the newly described $A$. wiesneri, were preliminarily evaluated for the first time. All three species were classified under threatened categories. Astragalus lalesarensis collected from only two localities in the alpine zone on dry rocky ground at 3500-3900 m elevation in the Kerman province (Fig. 3). Astragalus nigrohirsutus is limited to several localities in the Fars province, in dry limestone and screes, between 1750-2900 m elevation. Astragalus 
wiesneri has been collected only twice from the type locality in the alpine zone (nivale-subnivale zone) in a rocky place at 3500-3850 $\mathrm{m}$ in Bul Mt. Based on our results, $A$. lalesarensis, $A$. nigrohirsutus and $A$. wiesneri, are recommended to be treated as 'critically endangered' (CR B2 ab i, ii, iv), 'vulnerable' (VU B1 ab I, ii, iv) and 'critically endangered' (CR B1 + B2 ab iii), respectively (Table 1).

Notes. - Two different specimens from two different localities are present on the herbarium sheet of the Stapf's collection, one from Bul Mt. (A. wiesneri, K 000911588 , WU 0120162, WU 0120163) and another one from Abbas-Ali Mt. (A. murinus, K 000911587, WU 0120160, WU 0120161 cited by Podlech \& al. as A. wiesneri Stapf ined., 1.c. 1221).

\section{ACKNOWLEDGMENTS}

The authors wish to thank two anonymous reviewers who provided useful comments. Mr. D. Reich, from the WU herbarium, for sending photographs of specimens collected by O. Stapf, and Dr. Mirtadzadini for the photo of $A$. lalesarensis.

\section{REFERENCES}

Bachman S., Moat J., Hill A.W., de la Torre J. \& Scott B. 2011. Supporting Red List threat assessments with GeoCat: geospatial conservation assessment tool. Zookeys 150: 117-126.

Bornmüller J.F.N. 1937. Iter Persico-turcicum 1892-1893. Beiträge zur Flora von Persien, Babylonien, Assyrien, Arabien (Fortsetzung I). Beihefte zum Botanischen Centralblatt 7: 247-294.

Doyle J.J. \& Doyle J.L. 1987. A rapid DNA Isolation procedure for small quantities of fresh leaf tissue. Phytochemical Bulletin 19: 11-15.

Edgar R.C. 2004. Muscle: multiple sequence alignment with high accuracy and high throughput. Nucleic Acids Research 32: 1792-1797.

Hill A.W. \& Salisbury E.J. 1947. Index Kewensis Plantarum Phanerogamarum Supplementum Decimum: Nomina et Synonyma Omnium Generum et Specierum ab initio Anni. Oxford University Press, London.

IUCN. 2019. Guidelines for using the IUCN Red List categories and criteria. Version 14. Prepared by the standard and petitions Subcommittee of the IUCN Species Survival Commission. https://www.iucnredlist.org/ documents/RedListGuidelines.pdf [accessed Aug. 2019]

Kalyaanamoorthy S., Minh B.Q., Wong K.F., Haeseler A. \& Jermiin L.S. 2017. ModelFinder: fast model selection for accurate phylogenetic estimates. Nature Methods 14: 587-589.

Kumar S., Stecher G., Li M., Knyaz C., \& Tamura K. 2018. MEGA X: Molecular Evolutionary Genetics Analysis across computing platforms. Molecular Biology and Evolution 35: 1547-1549.

Lock G.M. \& Simpson K. 1991. Legumes of West Asia, a Check-list. Kew, Royal Botanical Garden.

Maassoumi A.A. 2016. Flora of Iran, Fabaceae (Astragalus II) 85: 242-288. Tehran: Research Institute of Forests and Rangeland.

Maassoumi A.A. 1998. Astragalus in the Old World, check-list. Tehran: Research Institute of Forests and Rangeland.

Maassoumi A.A. 2020a. http://astragalusofworld.com
Maassoumi A.A. 2020b. A checklist of Astragalus in the world. Tehran: Research Institute of Forests and Rangelands (in press).

Miller M.A., Pfeiffer W. \& Schwartz T. 2010. Creating the CIPRES science gateway for inference of large phylogenetic trees. In: Proceedings of the Gateway Computing Environments Workshop (GCE). New Orleans, Louisiana.

Morton A. 2009. DMAP for Windows. Distribution map software 7.3. Berkshire.

Naderi-Safar K., Kazempour-Osaloo Sh., Maassoumi A.A. \& Zarre S. 2014a. Molecular phylogeny of Astragalus section Anthylloidei (Fabaceae) inferred from nrDNA ITS and plastid rpl32-trnL(UAG) sequence data. Turkish Journal of Botany 38: 637-652.

Naderi-Safar K., Kazempour-Osaloo Sh. \& Maassoumi A.A. 2014 b. Re-assessment of subspecific taxa in Astragalus section Anthylloidei (Fabaceae) based on molecular evidence. Progress in Biological Sciences 4: $219-234$

Podlech D. 1988. Revision von Astragalus L. Sect. Caprini DC. Mitteilungen der Botanischen Staatssammlung München 25: 1-924.

Podlech D., Zarre S.H. \& Maassoumi A.A. 2001. Papilionaceae IV, Astragalus II. In: Rechinger K.H. (ed.), Flora Iranica, 175: 52-126. Akademische Verlagsgesellschaft Salzburg (AVESA).

Podlech D., Zarre S.H. 2013. Taxonomic Revision of the Genus Astragalus L. (Leguminosae) in the Old World, 2. Vienna: Naturhistorischen Museum Wien.

Posada D. 2008. jModelTest: Phylogenetic Model Averaging. Molecular Biology and Evolution 25: 1253-1256.

Rambaut A. 2018. FigTree Version 1.4.4. available at https://github.com/ rambaut/figtree/releases

Rechinger K.H., Dulfer H. \& Patzak A. 1958. Sirjaevii fragmenta astragalogica I.-III. - Osterr. Akademie DerWissenschaften MathematischNaturwissenschaftlische Klasse 95: 51-93.

Ronquist F., Teslenko M., Mark P., Ayres D., Darling D., Höhna S., Larget B., Liu L., Suchard, M.A. \& Huelsenbeck J. 2012. MrBayes 3.2: Efficient Bayesian Phylogenetic Inference and Model Choice across a Large Model Space. Systematic Biology 61: 539-542.

Stapf O. 1886. Die botanischen Ergebnisse der Polak'schen expedition nach Persien in Jahre 1882. Plantae collectae a Dre. J. E. Polak et Th. Pichler. II Theil. Denkschriften der Kaiserlichen Akademie der Wissenschaften, Wien. Mathematisch-naturwissenschaftliche Klasse 51: 271-346.

Sang T., Crawford D.J. \& Stuessy T.F. 1995. Documentation of reticulate evolution in peonies (Paeonia) using internal transcribed spacer sequences of nuclear ribosomal DNA: implications for biogeography and concerted evolution. Proceedings of the National Academy of Sciences of the United States of America 92: 6813-6817.

Thiers B. 2020 [continuously updated]. Index herbarium: A global directory of public herbaria and associated staff. New York Botanical Garden's Virtual Herbarium. Website: http://sweetgum.nybg.org/ih/ [accessed: 18 Apr. 2019].

Tietz S. \& Zarre S.H. 1994. Revision von Astragalus L. sect. Megalocystis Bunge (Fabaceae). Sendtnera 2: 287-364.

Trifinopoulos J., Nguyen L.T., Haeseler A. \& Minh B.Q. 2016. W-IQTREE: a fast online phylogenetic tool for maximum likelihood analysis. Nucleic Acids Research 44: W232-W235.

White J.T., Bruns T.D., Lee S.T. \& Taylor J.W. 1990. Amplification and Direct Sequencing of Fungal Ribosomal RNA Genes for Phylogenetics. In: Innis D.H. (ed.), PCR protocols: a guide to methods and applications, 31: 315-322. Academic Press, San Diego. 
APPENDIX 1. Voucher information of the Astragalus taxa included in the phylogenetic analysis with their corresponding GenBank accession numbers. Newly generated sequences are marked with an asterisk.

Astragalus anthylloides Lam., Turkey, Nydegger 43063 (MSB), AB908447; A. crassispinus Bunge, Iran, Anonymous 15394 (FUMH), AB908453; A. ebenoides Boiss., Iran, Maassoumi \& Mirhosseini 59421 (TARI), AB908445; A. keratensis Bunge, Iran, Maassoumi \& Zarre 71945 (TARI), AB908454; A. khoshjailensis Širj. \& Rech.f., Iran, Maassoumi. 47580 (TARI), AB052010; A. lalesarensis Bornm. 1, Iran, Mirtadzadini s.n. (TARI), AB908455; A. lalesarensis Bornm. 2, Iran, Fatehi 61184 (IRAN), LC597011*; A. murinus Boiss., Iran, Assadi \& Abouhamzeh 46094 (TARI), AB052008; A. raddei Basil., Iran, Maassoumi \& Mozaffarian 79577 (TARI), AB908452; A. remotiflorus Boiss., Iran, Assadi \& Miller 25162 (TARI), AB908446; A. submitis Boiss. \& Hohen., Iran, Mozaffarian \& Maassoumi 47960 (TARI), AB052009; A. yushensis T.Sabaii, Zarre \& Podlech, Iran, Maassoumi 55131 (TARI), AB999651; A. szovitsii Fisch. \& C.A.Mey., Iran, Assadi 86737 (TARI), AB908450; A. tortuosus DC., Iran, Fattahi \& Khaledian 438 (TARI), AB908451; A. wagneri Bunge, Iran, Assadi 85298 (TARI), AB908457; A. wiesneri Maassoumi \& Pahlevani, Iran, Pahlevani \& Ghamghami 76643 (IRAN), LC597012*; A. nigriohirsutus (Tietz \& Zarre) Borjian, Maassoumi \& Assadi, Iran, Mozaffarian s.n. (TARI), AB999650; A. melanogramma Boiss., Iran, Wendelbo \& Assadi 11451 (TARI), AB999649; A. pseudomurinus Naderi Safar \& Maassoumi, Iran, Mozaffarian 63931 (TARI), AB999648; A. coluteopsis Parsa, Iran, Zarre \& al. 39983 (TUH), AB908454; A. coluteoides Willd., Lebanon, Frederic Medail FCOA1 (MARS), JX284071; A. naghadehensis (Tietz \& Zarre) Naderi Safar \& Maassoumi, Iran, Siami 5413 (TARI), AB999647; A. ovigerus Boiss., Iran, Sardari 3107 (TARI), LC529229; A. hezarensis Zarre \& Podlech, Iran, Mirtadzadini 1383-7-3 (TMUH), LC529219; A. horridus Boiss., Iran, Mozaffarian 54874 (TARI), AB052002; A. straussii Hausskn. ex Bornm., Iran, Mozaffarian \& Maassoumi 47793 (TARI), AB052012; A. campylanthus Boiss., Iran, Mozaffarian \& Maassoumi 47790 (TARI), AB052028; A. macrosemius Boiss. \& Hohen., Iran, Wendelbo \& Cobham 14495 (TARI), AB052030; A. eriostomus Bornm., Iran, Mozaffarian. 63794 (TARI), AB052007; A. cephalanthus DC., Iran, Mozaffarian \& Maassoumi. 47788 (TARI), AB052027; A. glaucacanthos Fischer, Iran, Assadi et al. 33356 (TARI), AB052017; A. semnanensis Bornm. \& Rech.f., Iran, Mozaffarian 58865 (TARI), AB231118; A. sinicus L., Japan, Kazempour-Osaloo 1999-01 (TARI), AB051965; A. aegobromus Boiss. \& Hohen., Iran, Maassoumi 55116 (TARI), AB051953. 